\title{
Fabrication of a vermifiltration unit for wastewater recycling and performance of vermifiltered water (vermiaqua) on onion (Allium cepa)
}

\author{
Chandrajeet Kumar ${ }^{1}$ (1) $\cdot$ Ashok K. Ghosh ${ }^{2}$ (1)
}

Received: 19 June 2018 / Accepted: 6 February 2019 / Published online: 6 March 2019

(c) The Author(s) 2019

\begin{abstract}
Purpose Vemifiltration units are sludge-free, noise-free and low- or no-electricity-requiring systems of operation. The aim of this study was to emphasize wastewater treatment by vermifiltration technology using waste-eater earthworms to highlight the benefits of clean and nutritive vermifiltered water (vermiaqua) uses in agriculture to the farmers.

Methods Wastewater sample was filtered through fabricated vermifiltration unit to study physio-chemical and biological properties of vermiaqua and uniform-sized Allium cepa (Onion) bulbs were kept for root germination at different concentrations $\left(10^{-1}, 10^{-3}, 10^{-5}, 10^{-7}, 10^{-9}\right)$ of wastewater and vermiaqua at room temperature for 5 days to study impacts of vermiaqua on morphological and cytological characteristics of onion.

Results Vermiaqua was odorless, pale yellow in appearance, lower in turbidity and highly nutritive as ammonia and nitrate contents were highly increased. In E. coli-free vermiaqua, $\mathrm{BOD}_{5}$ loads were also reduced by $91 \%$. Almost all vermiaquatreated root germinations were 'accelerated', whereas all wastewater-treated root germinations were 'retarded'. The highest number of germinated roots was counted at $10^{-5}$ concentration of vermiaqua, whereas at the same concentration of wastewater no germination was observed. Many types of chromosomal abnormalities were observed at metaphase and anaphase stages of wastewater-treated roots, whereas the single type of chromosomal abnormality was observed at anaphase stage of vermiaqua-treated roots.

Conclusions Earthworms upgraded the performance of fabricated systems having integrated methods (biological, chemical and physical) of wastewater purification. Morphological and cytological studies revealed vermiaqua highly promoted the root germination without any chromosomal abnormalities.
\end{abstract}

Keywords Allium cepa $\cdot$ Chromosomal abnormalities $\cdot$ Earthworms $\cdot$ Vermifiltration $\cdot$ Vermiaqua $\cdot$ Wastewater

\section{Introduction}

The Holy River Ganges is the largest river in India that provides water to about $40 \%$ of Indian population but unfortunately, it is being highly polluted by the discharge of untreated wastewater (both municipal and industrial) in which trashes, food wastes, dead bodies of animals, etc. can

Chandrajeet Kumar

mail4chandrajeet@yahoo.com

Ashok K. Ghosh

ashok.ghosh51@gmail.com

1 Department of Environment and Water Management, A.N. College, Patna, India

2 Bihar State Pollution Control Board, Patna, India be seen by our naked eyes. Wastewater is hazardous containing solids (fecal matters, heavy metals, minerals, urines, and organic substances). In 2012, the National Cancer Registry Program (NCRP) warned that people living near the bank of river Ganges are more prone to Cancers.

It does not mean that wastewater is not being treated in India to remove such solids, chemicals, and pathogens but the conventional wastewater treatment systems are not cleansing (disinfecting and detoxifying) them properly. Moreover, they require very high electricity consumption and many treatment plants do not operate regularly due to a shortage of power supply. Conventional wastewater treatment plants also create sludge which is a highly hazardous waste and another problem for society as they are not being properly disposed in secured landfills but thrown on the open lands. 
Under all these circumstances, our society needs an automated, self-regulated, no- or low-electricity, no-sludge, nonoise pollution, and maintenance-free wastewater treatment plants to get cost-effective clean (disinfected and detoxified) water for farm irrigation, domestic and industrial uses.

The vermifiltration technology fulfills all the necessary requirements for the reuse of treated water in society and due to highly nutritive properties (rich in NKP) of vermiaqua, it becomes more useful for irrigation in agriculture by saving huge groundwater and also fertilizers for the farmers-the 'Feeders of Society'.

\section{The need of vermifiltration technology (VFT) for wastewater purification and reuse}

\section{To overcome the impending water crisis due to depleting water resources of earth: a potential threat to human survival on earth}

Out of the total water available on earth, $97.5 \%$ is saline in the oceans and 2\% is frozen in the Alps. Only less than $1 \%$ is available for human use and consumption. Alone $85 \%$ of the fresh water of earth is used in global agriculture due to heavy use of agrochemicals and now global water use is tripled in food production for human society. On the other hand, water is a depleting resource all over the world with the groundwater level constantly going down leading to a severe water crisis in the future. UNEP has warned that within a few decades, $50 \%$ of the population would face water scarcity. Reuse of wastewater generated by society gives a big hope to civilization to prevent the crisis.

Vermifiltration is a bio-treatment technology by earthworms for greater utilization of clean vermifiltered wastewater in society instead of discharging them in the rivers and water bodies. They are almost electricity-free or low-energy, noise-free, odor-free as well as a sludge-free system with several other environmental and economic advantages and benefits over the conventional wastewater treatment technologies. The vermifiltered water (vermiaqua) becomes highly nutritive, pathogen free, odor free, chemical free, sterile and neutral in $\mathrm{pH}$ which is suitable for all non-potable uses such as for irrigation in farms, gardens, toilet flushing, washing in homes, institutions and for industrial uses (Sinha et al. 2012).

\section{Earthworms: the creator of earth and the unheralded soldiers of mankind}

Earthworms are 'Living Treasure of Earth'. The Philosopher, Sir Aristotle named earthworms the 'Intestine of Earth' and Sir Charles Darwin named the 'Unheralded Soldiers of Mankind and Friends of Farmers,' (Darwin et al. 1903). According to the book entitled 'The Formation of Vegetable Mould
Through the Action of Worms' written by Sir Charles Darwin in 1881, earthworms survived even after the distinction of dinosaurs from the earth and has a long history in waste management (Darwin 1881).

Nobody and nothing can be compared with earthworms and their positive influence on the whole living Nature. They create soil \& improve soil's fertility and provides critical biosphere's functions: disinfecting, neutralizing, protective and productive. "Dr. Anatoly Igonin"

Globally, 4400 species of earthworms are reported out of which 509 species have been reported in India, out of them, e.g. Eisenia fetida, Perionyx excavatus, and Eudrillus eugeniae are most commonly available species used in waste management and having maximum bio-accumulating potency (Roberts and Dorough 1985). Earthworms are long and brown color in appearance having a symmetrical and segmented body without bones that perform a normal physiological function under $60-75 \%$ moisture and $5-29{ }^{\circ} \mathrm{C}$ temperature. The average life span of earthworm is about 3-7 years, mostly depending upon types of species and environmental circumstances. They are bisexual organisms reproducing up to three cocoons/worm/week and from each cocoon, about 10-12 baby earthworms emerge (Sinha et al. 2010). They are also able to survive in 'saline soils' (Kerr and Stewart 2003) and in $1.5 \%$ crude oil containing 'Toxic Organic Pollutants' (OECD 2004).

\section{Earthworms: great waste managers, consumers, and degraders on earth}

Most of the earthworm species consume organic wastes (solid wastes and wastewater), half of their body weight in a day except $E$. fetida that consumes waste equal to their body weight in a day to increase their population by two times in every 2-2.5 months (Viswanathan et al. 2005). Earthworm's gut symbiotically occupies microbes having biodegradation properties to degrade cellulose present in the organic wastes (Sinha et al. 2008). Earthworms with the help of gut microbes increase the degradation rate of waste by increasing metabolic activity (Rajpal et al. 2011). Out of all the invertebrates present in the soil, only Earthworms play a major role in carbon turnover, nitrogen mineralization, cellulose degradation, and humus accumulation, etc. from the organic wastes (Römbke et al. 2005).

\section{Ability to kill pathogens and disinfect the medium in which it lives}

Earthworm selectively attacks the pathogens present in the wastewater by 'antibiotic-producing microbes' which occupies in their gut and by secreting 'coelomic fluid' having 
strong bactericidal potency to purify them completely 'disinfected' as well as 'odorless' (Valembois et al. 1982).

\section{Ability to bio-accumulate toxic chemicals and detoxify the medium in which it lives}

Earthworms bio-accumulate and biodegrade endocrinedisrupting chemicals, heavy metals, and pesticides (organochlorine pesticides) found in organic (polycyclic aromatic hydrocarbons) and inorganic wastes (lead), and wastewater. Earthworms render the toxic chemicals harmless by combining them with special proteins called 'metallothioneins' in them or by changing their 'ionic' states (Sinha et al. 2010; Markman et al. 2007).

\section{Voracious waste-eater species of earthworms detoxifying and disinfecting the end-products}

\section{Role of earthworms in vermifiltration technology (VFT)}

Earthworms function as a bioreactor having physical process (aeration, grinding, crushing), chemo-degradation process (coelomic fluids, protease, lipase, amylase, cellulase, and chitinase) and biodegradation process (microbes present in gut) and all these combined processes make earthworm's whole body to behave as a bio-filter that adsorbs pollutants from wastewater and highly reduces BOD, COD, TDS, TSS, and turbidity (Sinha et al. 2012).

Vermifiltration technology is a self-promoted, self-regulated process for treatment of sewage (Bajsa et al. 2004) that can be 'decentralized' to treat small towns and residential colony wastewaters thus reducing the long-distance transmissions of wastewater, and saving time and energy (Taylor et al. 2003). They can also be used for the treatment of industrial and livestock wastewater which have very high BOD, COD, TDSS loads and toxicity. They are significantly reduced by more than 70-80\% after vermifiltration (Hartenstein and Bisesi 1989). VFT reduces $95 \%$ biological oxygen demand, $85 \%$ chemical oxygen demand, $90-92 \%$ total dissolved solids, $95 \%$ total suspended solids and turbidity, and $99 \%$ fecal coliforms from wastewater while increases dissolved oxygen from 0 to $4-5 \mathrm{ppm}$, nitrates $\left(\mathrm{NO}_{3}\right)$ from 10-20 ppm to $50 \mathrm{ppm}$, phosphates $\left(\mathrm{P}_{2} \mathrm{O}_{5}\right)$ from 1-2 ppm to 5-7 ppm and the potassium (k) from $10-15 \mathrm{ppm}$ to 20-25 ppm in the vermifiltered water (Sinha et al. 2012).

\section{The mechanism of action of earthworms in vermifiltration of wastewater}

- Microbes present in the gut of earthworms and enzymes present in secreted coelomic fluid stimulate biodegradation process. The sand and pebble layers of the vermifil- ter unit also provide a wonderful site for the growth of aerobic microbes.

- The pollutants in wastewater are adsorbed and stabilized by the earthworms and the aerobic microbes excreted from the gut of earthworms.

- The vermicast offers excellent 'hydraulic conductivity' in vermifilter layers because of being porous-like sand for cleaning sewage.

- Coelomic fluid also degrades harmful and ineffective microbes from wastewater thus preventing choking of the medium. (Sinha et al. 2012)

\section{Factors affecting vermifiltration of wastewater}

\section{Population density}

Biomass in the vermifilter unit varies under optimum temperature and moisture due to the multiplication of their number in at least every 2 months (Komarowski 2001).

\section{Hydraulic retention time (HRT)}

During filtration process contact between wastewater and earthworm's body must be maintained for $1-2 \mathrm{~h}$.

\section{Cytotoxicity, mutagenicity, and genotoxicity in onion crops} due to irrigation by untreated wastewater

Industrial and municipal wastewaters which are directly poured into the rivers without proper treatment becomes potentially 'cytotoxic' to river water (Egito et al. 2007) which can cause severe mutagenic effects directly on human life (Grover and Kaur 1999). Plant root systems are very sensitive and effective materials for detection of mutagenicity, genotoxicity, and cytotoxicity caused by pollutants (Gopalan 1999; Grant 1999). Plant roots are first to be exposed to chemical contaminants present in wastewater and soil (Fiskesjö 1988). According to the "International Program on Plant Bioassays (IPPB)" Allium cepa (Onion) root tip can be used for monitoring environmental pollutants. Onions are easily available everywhere throughout the year and their roots grow very fast which can be used to test cytotoxicity, genotoxicity and mutagenicity effects (Ateeq et al. 2002; Amal 2002) by squashing and staining of the root tips. Cytotoxic effect of wastewater increases with an increase in wastewater concentration and causes 'stickiness and abnormality' in chromosomes (Amal 2002), and 'root growth inhibition' and 'root length decrement' (Egito et al. 2007) due to inhibition in cell division and cell cycle (Grant 1999; Evseeva et al. 2003). Root growth inhibition and growth retardation occur also due to high load of COD in wastewater which creates disturbance between promoter and inhibitors of endogenous 'growth regulators' (Ukaegbu 
and Odeigah 2009). Wastewater effluents also causes 'genotoxic' effect which includes 'non-disjunction of chromosomes', 'induction of micronucleus formation', 'spindle poisoning' (Dash et al. 1988; Chandra et al. 2005), 'crochet Hooks', 'C-tumors' (Amal 2002) and 'laggard metaphase chromosome' (Firbas 2013). The presence of 'cytotoxic' or 'genotoxic' substances in the river waters can be identified by all these signs in plant roots (Bakare et al. 2009) which can directly transfer into human beings through plants in the ecosystem as a potential risk to human health (Olorunfemi et al. 2011).

\section{Materials and methods}

\section{Fabrication of a vermifiltration unit (80 I)}

Before fabrication of a complete vermifiltration unit, design as shown in Fig. 1 and microscopic view as shown in Fig. 2 for the same were designed. Accordingly, wastewater (Influent) container, plastic drum (80 l) and vermifiltrate (Effluent) container were assembled on a movable iron rack as shown in Fig. 3. Influent container having water controller knob was adjusted to trickle down @ $15 \mathrm{ml}$ wastewater per minute onto the top layer of vermibed whose bottom was connected with vermifiltrate (effluent) container through a water pipe for collecting vermifiltrate (vermiaqua). Plastic drum was indepth filled by graded layers of stones, sand and humid soil followed by vermicompost containing earthworms (Fig. 4) on top for preparing a vermibed. Systematic illustration of different layers is mentioned in Table 1 and images of graded layers are represented in Fig. 5.

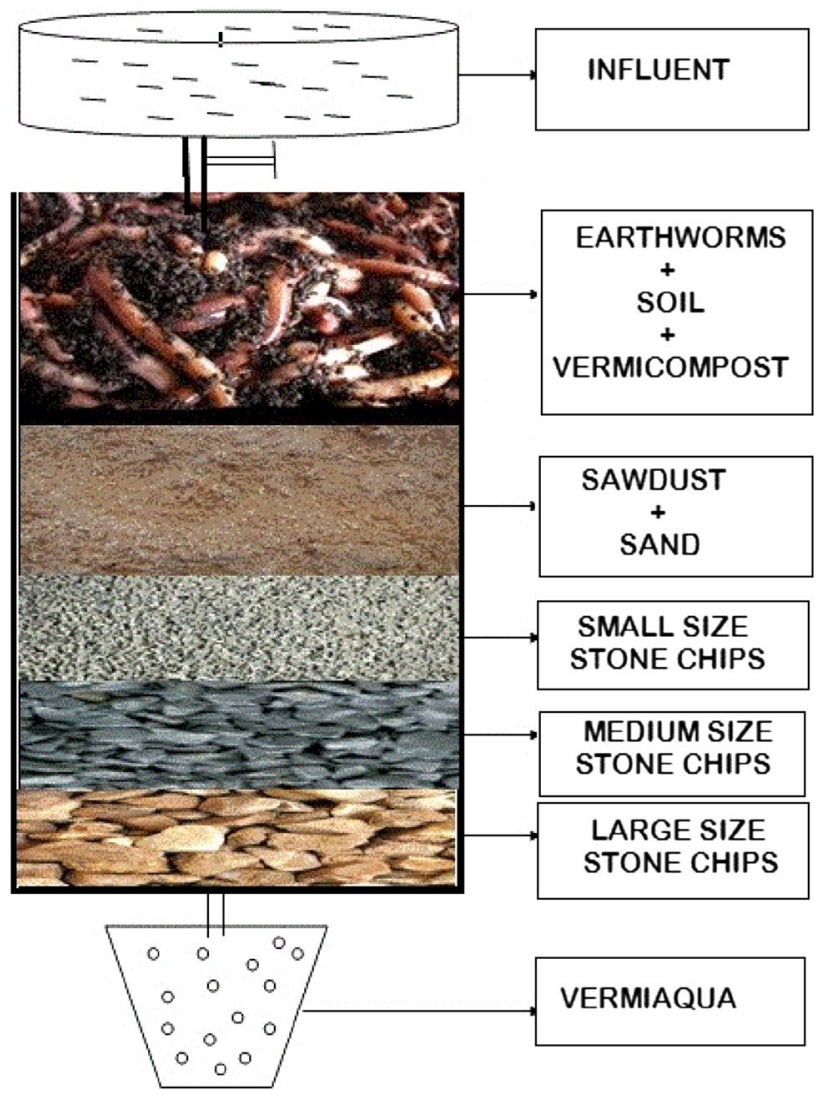

Fig. 2 Microscopic view of a vermifilter bed

\section{Wastewater sampling}

River Ganges is being highly polluted by the discharge of untreated wastewater (both municipal and industrial) and
Fig. 1 Design of a fabricated vermifiltration unit

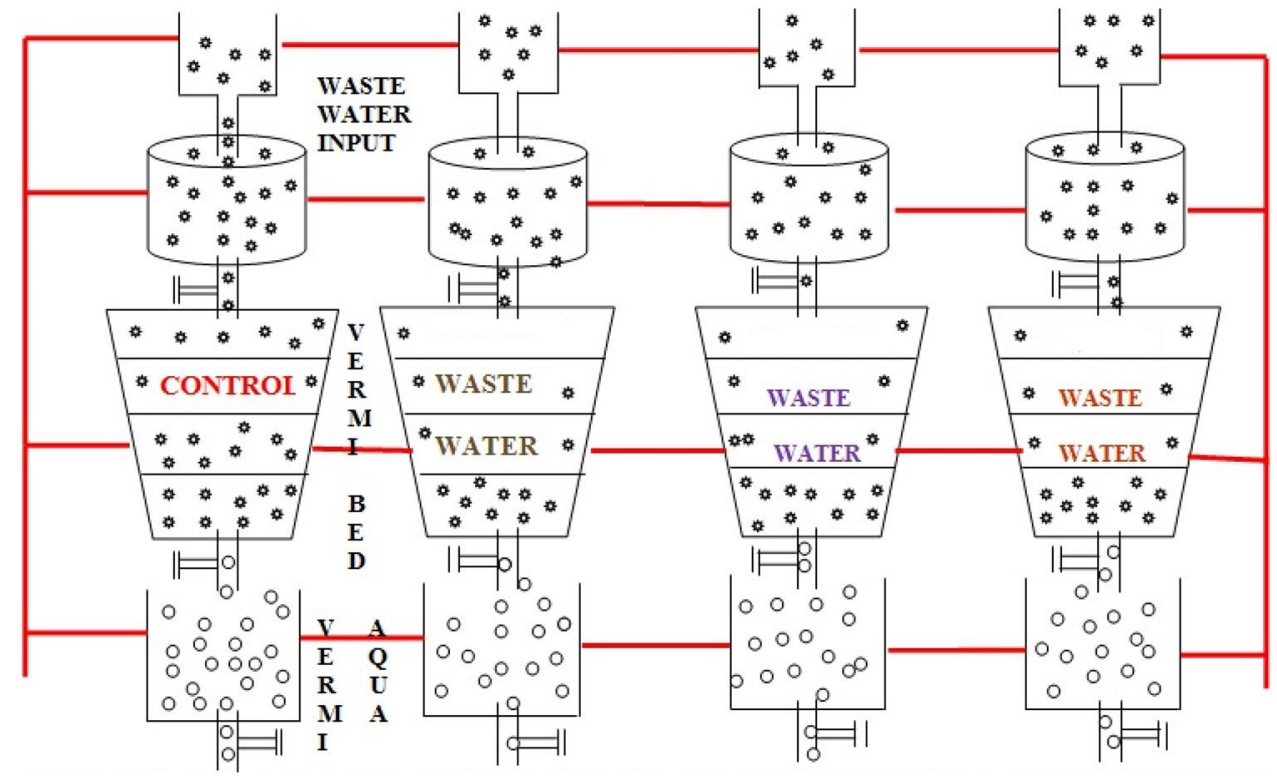




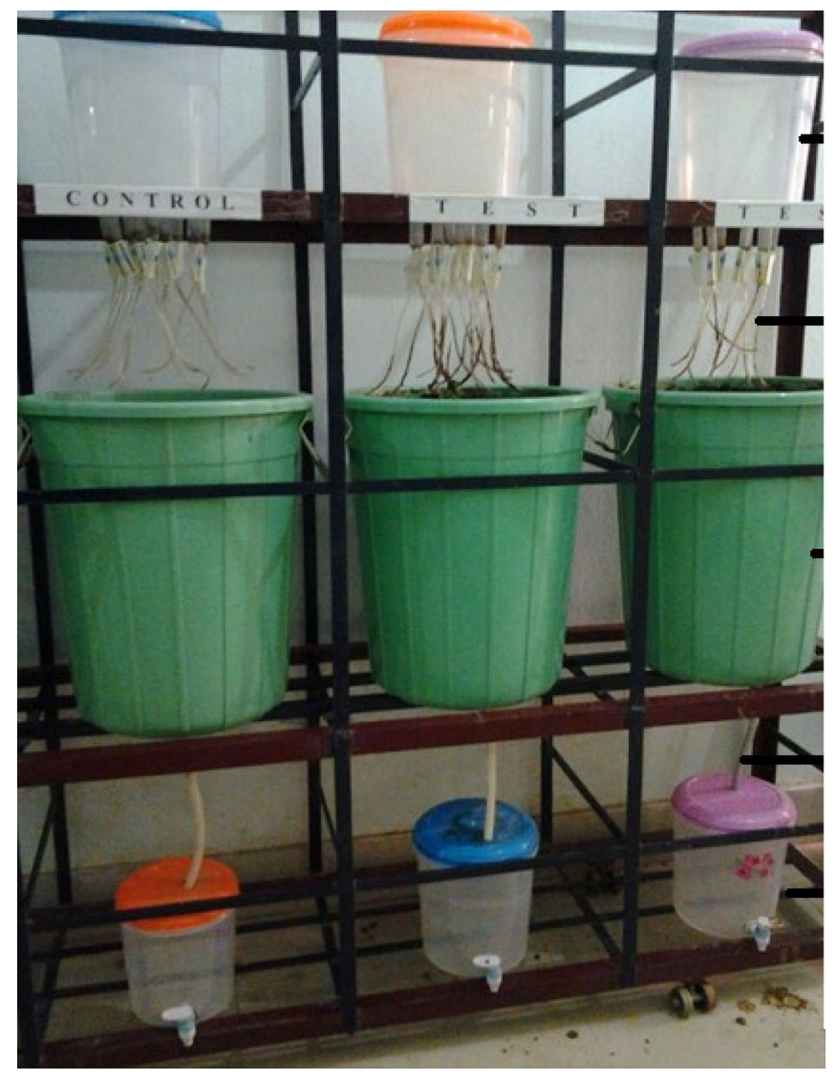

Fig. 3 Assembled vermifilteration unit

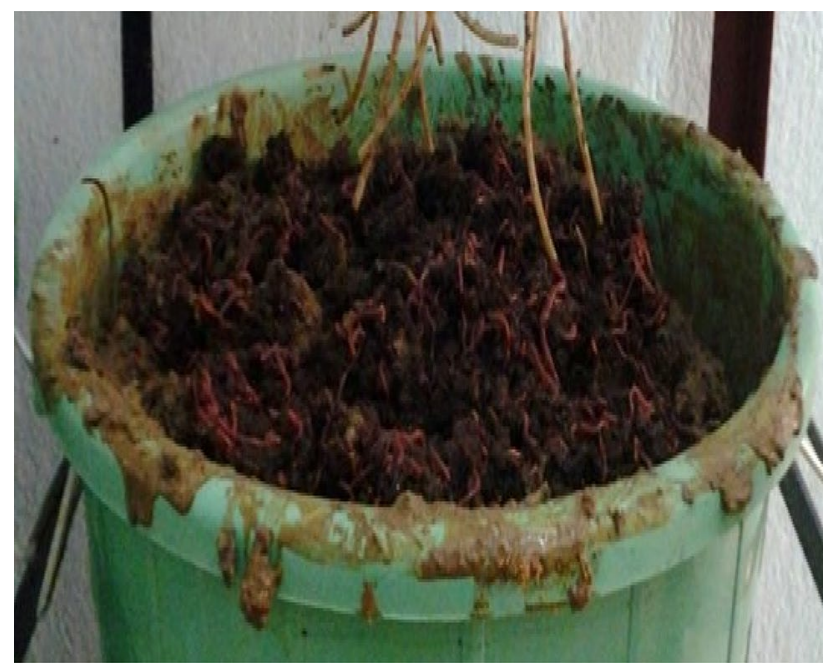

Fig. 4 The top layer of vermifilter bed

untreated river water is directly used by the farmers for crops and vegetable production. Wastewater was sampled in a pre-treated BOD bottle (washed with nitric acid) as shown in Fig. 6 from "Anta Ghat, Patna" site.
Table 1 Graded layers of the vermibed

\begin{tabular}{|c|c|c|c|}
\hline \multirow[t]{2}{*}{ Layers } & \multirow{2}{*}{$\begin{array}{l}\text { Layer thick- } \\
\text { ness and size } \\
(\mathrm{cm})\end{array}$} & \multicolumn{2}{|l|}{ Materials } \\
\hline & & Test unit & Control unit \\
\hline Top Layer & 30 & $\begin{array}{l}\text { Soil + vermicom- } \\
\text { post + earth- } \\
\text { worms }^{\text {a }}\end{array}$ & $\begin{array}{l}\text { Soil + vermicom- } \\
\text { post }\end{array}$ \\
\hline 2nd layer & 20 & Sand + sawdust & Sand + sawdust \\
\hline 3rd layer & 10 & $\begin{array}{l}\text { Small size peb- } \\
\text { bles }\end{array}$ & Small size pebbles \\
\hline 4th layer & 10 & $\begin{array}{l}\text { Medium size } \\
\text { pebbles }\end{array}$ & $\begin{array}{l}\text { Medium size } \\
\text { pebbles }\end{array}$ \\
\hline 5th layer & 10 & $\begin{array}{l}\text { Large size peb- } \\
\text { bles }\end{array}$ & Large size pebbles \\
\hline Bottom layer & $01 \mathrm{~mm}$ & $\begin{array}{l}\text { Microfibre Cot- } \\
\text { ton cloth layer }\end{array}$ & $\begin{array}{l}\text { Microfibre Cotton } \\
\text { cloth layer }\end{array}$ \\
\hline
\end{tabular}

$\mathrm{cm}$ centimeter, $\mathrm{mm}$ millimeter

${ }^{\mathrm{a}} 1 \mathrm{~kg}$ adult earthworms for treating 11 of wastewater

\section{Vermifiltration of wastewater and collection of vermifiltered water (vermiaqua)}

Collected wastewater was directly poured into pre-treated (washed with nitric acid) influent container and allowed to filter through the vermifilter bed, and the treated water (vermifiltrate or vermiaqua) was collected into pre-treated (washed with nitric acid) effluent container and transferred to a pre-treated (washed with nitric acid) BOD bottle as shown in Fig. 6 to store at room temperature in dark.

\section{Physico-chemical and biological analysis of wastewater and vermiaqua}

The physico-chemical and biological parameters are mentioned in Table 2 and all the mentioned parameters were analyzed in triplet and averaged during working condition for the authentic result. Biological parameter (E. coli test) was tested by Aquacheck Coliform vial presented in Fig. 7 .

\section{Germination of onion (Allium cepa) roots at different concentrations of vermiaqua and wastewater}

The Allium cepa test was carried out at different concentrations $\left(10^{-1}, 10^{-3}, 10^{-5}, 10^{-7}, 10^{-9)}\right.$ of vermiaqua and wastewater along with control (tap water) as shown in Fig. 8 and allowed to germinate uniform-sized onion bulbs on same concentrations for 5 days (Fig. 9) at room temperature.

\section{Preparation of cytological slides by squashing technique}

Germinated root tip by every concentration was kept in a pre-treatment solution (para-dichlorobenzene solution) for 
Fig. 5 Different layers of vermifilter bed
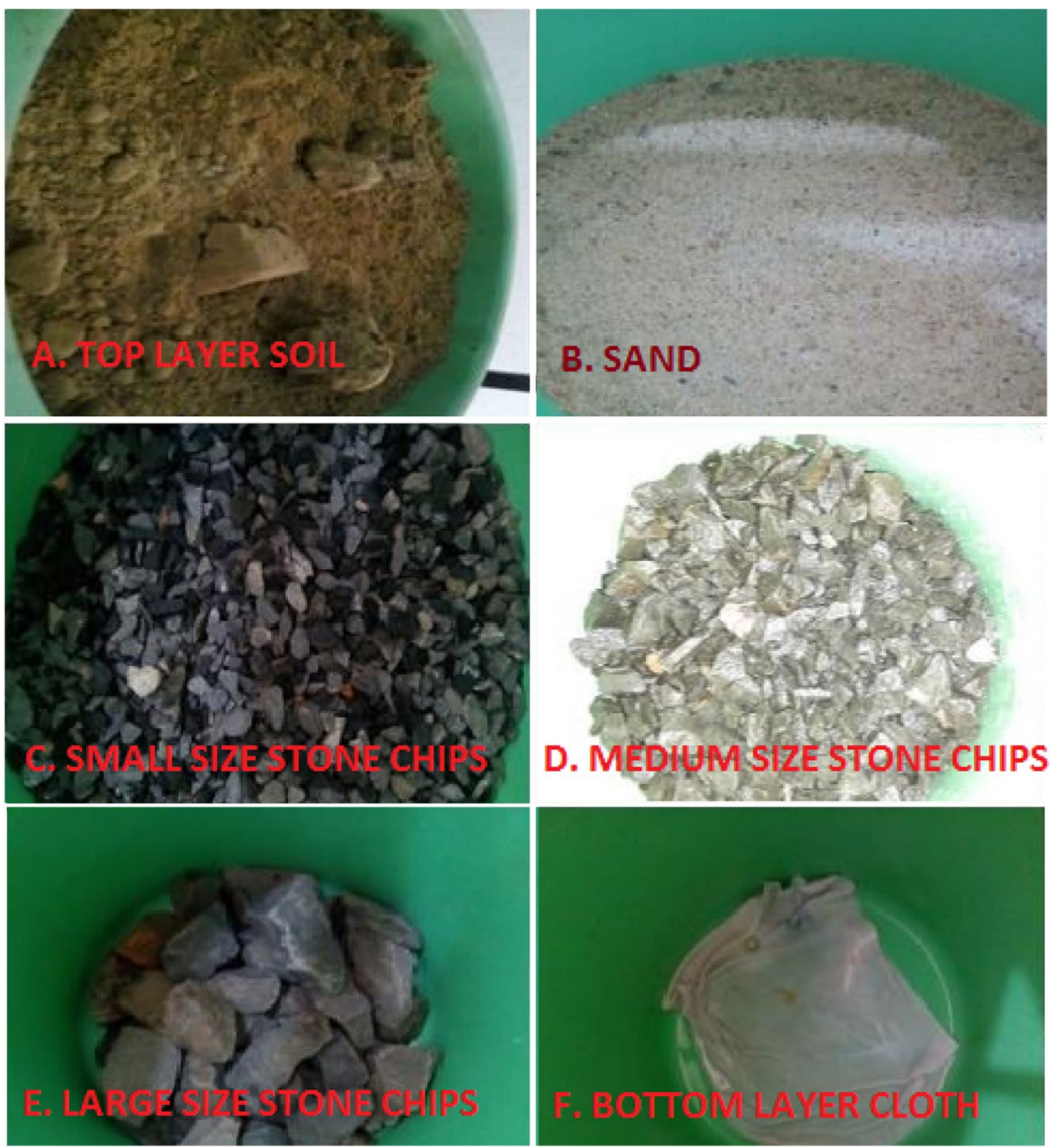

Fig. 6 Collected wastewater (left) and vermiaqua (right)
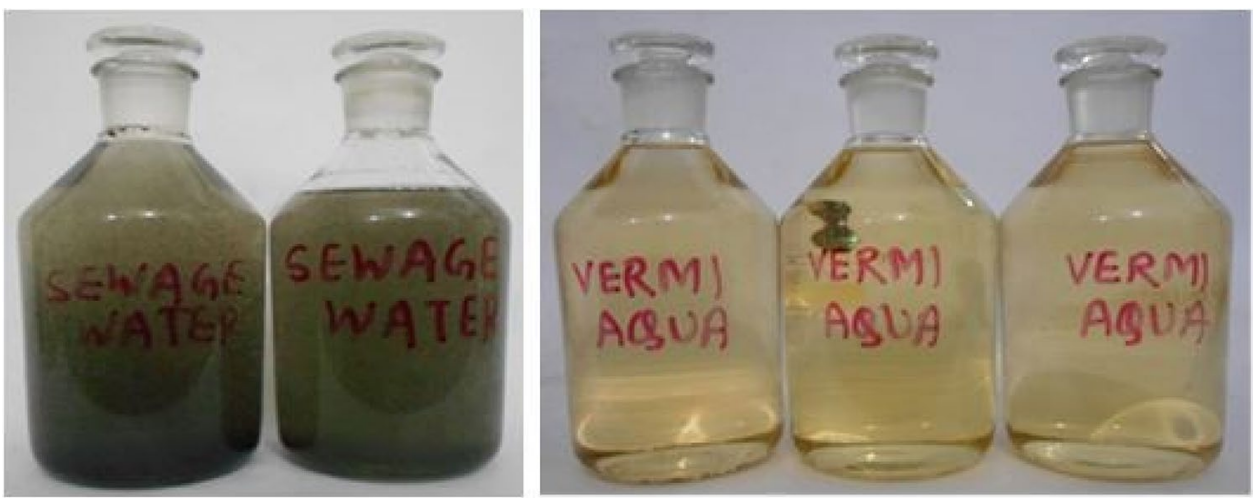

$2 \mathrm{~h}$ and transferred to the fixative solution (ethanol:acetic 3:1) for $24 \mathrm{~h}$. Thereafter, for cytological studies fixed root tips were put on glass slide after staining by acetocarmine.
Coverslips were also placed over the stained root tip for proper tapping-squashing and to observe all the stages of the division under a microscope. 
Table 2 Analysis of physico-chemical and biological parameters of control, wastewater and vermiaqua

\begin{tabular}{llll}
\hline Parameters analysed & Control & Wastewater & Vermiaqua \\
\hline Odour & Unpleasant & Unpleasant & Odourless \\
Colour & Hazy & Dark Brown & Pale Yellow \\
Turbidity (NTU) & 15.0 & 100 & 5.0 \\
pH & 8.2 & 8.8 & 7.5 \\
Nitrate (mg/l) & 3.0 & 1.0 & 10.0 \\
Ammonia (mg/l) & 0.8 & 0.4 & 3.0 \\
Iron (mg/l) & 1.5 & 3.0 & 0.3 \\
Phosphorous (mg/l) & 0.1 & BDL & B.D.L \\
BOD (mg/l) & 30 & 218 & 19 \\
E. coli & ++++ & ++++ & ----- \\
\hline
\end{tabular}

BOD (biological oxygen demand); + positive; - negative; each value is average of 3 observations

$B D L$ below detectable limit

\section{Results and discussion}

\section{Physico-chemical and biological analysis of wastewater and vermiaqua}

In this current study, vermiaqua and untreated wastewater along with control were tested for comparative analysis of physico-chemical and biological parameters presented in Table 2. Vermifiltered (vermiaqua) was odorless, neutral in $\mathrm{pH}$, low in turbidity and nutritive as ammonia and nitrate contents were increased from 0.4 to $3 \mathrm{mg} / \mathrm{l}$ and from 1 to $10 \mathrm{mg} / \mathrm{l}$, respectively, after vermifiltration due to active microbial decomposition processes. Sinha et al. (2012) also reported approximately same fold increment in nitrate contents. Biotransformation of ammonia to nitrate, i.e. ammonification and nitrification, takes place by aerobic bacteria.
Earthworms provide suitable conditions such as neutral $\mathrm{pH}$ (7.5), optimum temperature $\left(23^{\circ} \mathrm{C}\right)$ and sufficient moisture and oxygen to vermibed for enhanced growth of aerobic microbes. Vermiaqua was also free from $E$. coli as tested by Aquacheck coliform vial test presented in Fig. 7. E. coli is a pathogenic and indicator organism for water sanitation. Likewise, $\mathrm{BOD}_{5}$ loads obtained in vermiaqua was also reduced by $91 \%$ as Sinha et al. (2012), also reported $95 \%$ decrement in $\mathrm{BOD}_{5}$ indicating a high decrement in pollutants.

\section{Effect of vermiaqua and wastewater on morphology of germinated roots}

Uniform-sized Allium cepa (Onion) bulbs were kept for root germination at different concentrations $\left(10^{-1}, 10^{-3}, 10^{-5}\right.$, $10^{-7}, 10^{-9}$ ) of wastewater and vermiaqua as shown in Fig. 8 and allowed to germinate for 5 days as presented in Fig. 9 . All the morphological properties of germinated roots are mentioned in Table 3. At all the concentrations, germinated roots were white in color as shown in Fig. 10. Almost all germinated roots treated by vermiaqua were 'accelerated' as well as 'straight rooted', whereas all germinated roots treated by wastewater were 'morphologically deformed' such as 'inhibited', 'stunned', 'crochet hook', 'wavy or curly'. The highest number of germinated roots was counted at $10^{-5}$ concentration of vermiaqua, whereas at the same concentration of wastewater no germination was observed as mentioned in Table 3. Likewise, the longest length of germinated roots was measured at $10^{-9}$ concentration of vermifiltrate only indicating vermiaqua and wastewater, respectively, promoted and inhibited germination as Egito et al. (2007), also reported on the basis of Grant (1999), and Evseeva et al. 2003 reports that wastewater caused 'root growth inhibition' and 'root length decrement' due to inhibition of cell division and cell cycle.
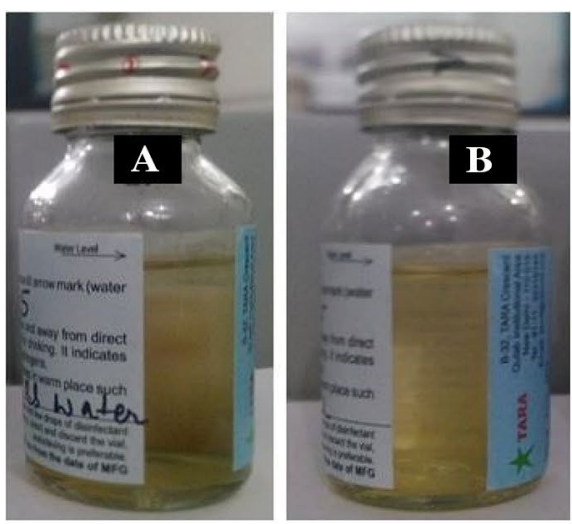

At $0 \mathrm{hr}$.
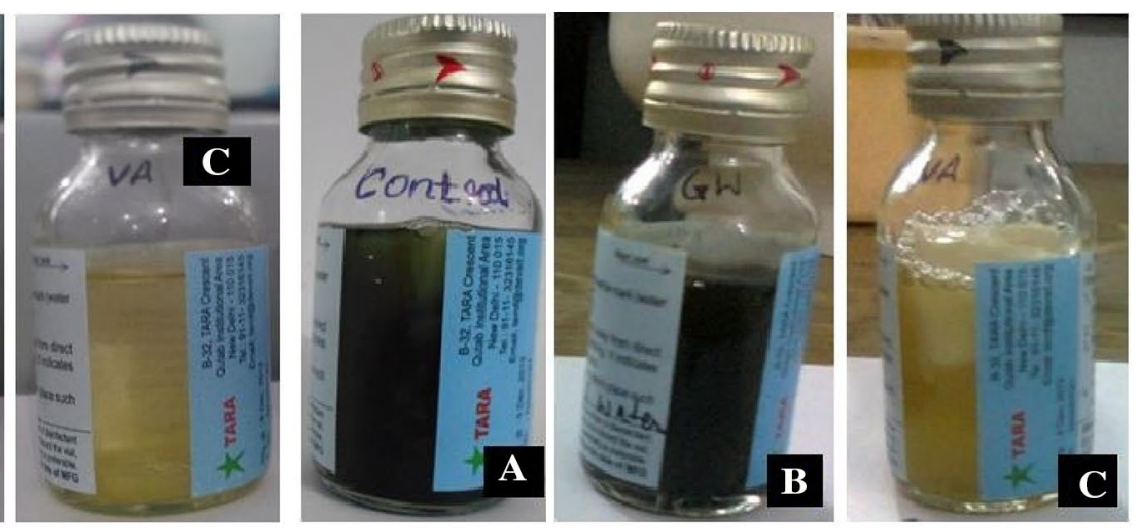

After 24 hrs.

Fig. 7 Aqua check vial containing A, control; B, wastewater; C, vermiaqua 


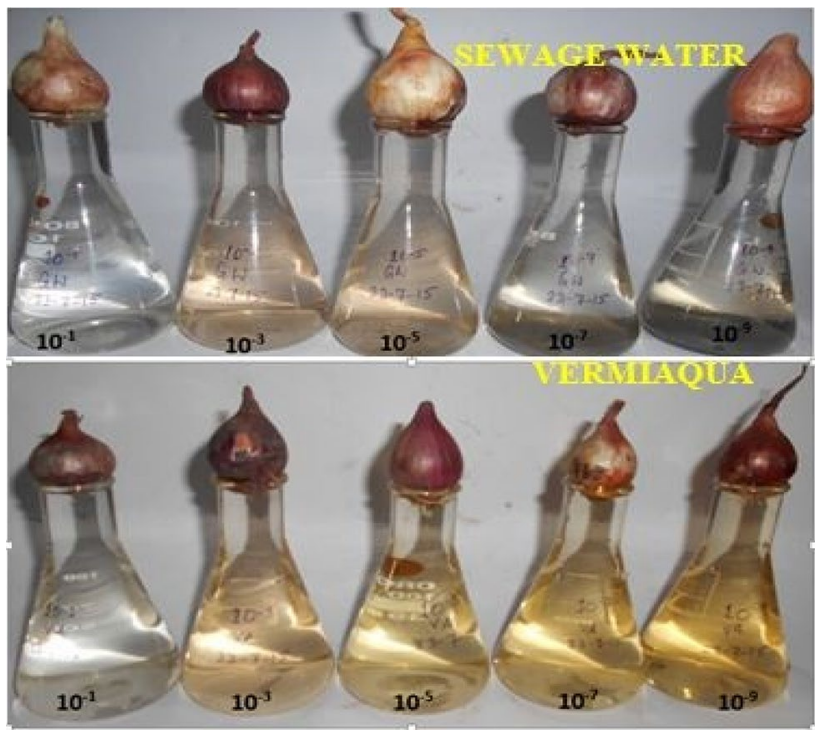

Fig. 8 Root germination on 1st day
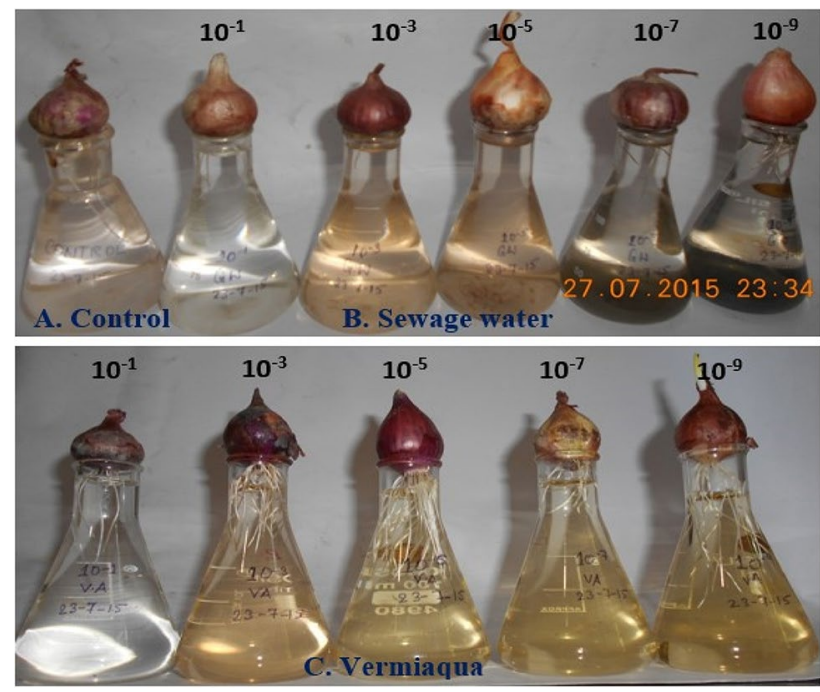

Fig. 9 Root germination on 5th day

\section{Effects of wastewater and vermiaqua uses on chromosome of germinated roots}

Since the highest number of germinated roots was found, respectively, at $10^{-5}$ and $10^{-9}$ concentrations of vermiaqua and wastewater as mentioned in Table 3; therefore, germinated roots of these concentrations were chosen for slide preparation and microscopic observations. Chromosomal abnormalities found in vermiaqua and wastewatertreated roots are mentioned in Table 4. Many types of chromosomal abnormalities (uneven separation of chromosomes, sticky chromosomes, laggard chromosomes, and chromosomal deletions) as shown in Fig. 11 were observed at metaphase and anaphase stages of wastewater-treated roots, whereas the single type of chromosomal abnormality (chromosomal dibridges) as shown in Fig. 12 was observed at anaphase stage of vermiaquatreated roots indicating a high occurrence of mutagenic and toxic compounds in sewage water. An old report by Amal (2002) and a recent report by Firbas (2013) also reported the same that wastewater effluents caused 'genotoxic' effects including 'crochet Hooks' and 'laggard metaphase chromosome'. Furthermore, Bakare et al. (2009) and Olorunfemi et al. (2011) reported cytotoxic' or 'genotoxic' substances in the river waters can directly transfer into human beings through plants in the ecosystem as a potential risk to human health.

\section{Conclusions}

The fabricated vermifiltration unit as shown in Fig. 3 was successfully operated at low cost with good efficacy without using electricity and role of vermiaqua (Fig. 6) in root growth and root germination by inhibiting chromosomal abnormalities upgraded its performance. Through this study, authors want to warn the farmers of India and the world, never to use the untreated sewage or any wastewater for irrigation in agriculture. It has become a common practice due to the growing scarcity of water all over the world. We also want to suggest the Govt. of India and all nations of the world to promote the vermifiltration technology by earthworms for wastewater treatment on a commercial scale and use the vermiaqua in farm irrigation as a good alternative to fresh water thus saving huge groundwater which is fast depleting all over the world. This will also reduce the use of chemical fertilizers as the vermiaqua is highly nutritive (rich in NKP). Vermifiltration technology has already been commercialized in India by TRANSPEK (Transchem Agritech) under the scientific guidance of Prof. Rajiv k. Sinha (prof. rajivksinha@gmail.com) and Dr. Mandar Prabhune (mandar.prabhune@transpek.com). Several vermifilter plants are operating in Gujarat and Maharashtra. All vermifiltered wastewater (vermiaqua) are being supplied to farmers. Similarly, several vermifilter plants are also working in Chile, Mexico and Venezuela by BIOFILTRO. 
Table 3 Morphological properties of germinated roots

Fig. 10 Root germination at different concentration of wastewater and Vermiaqua
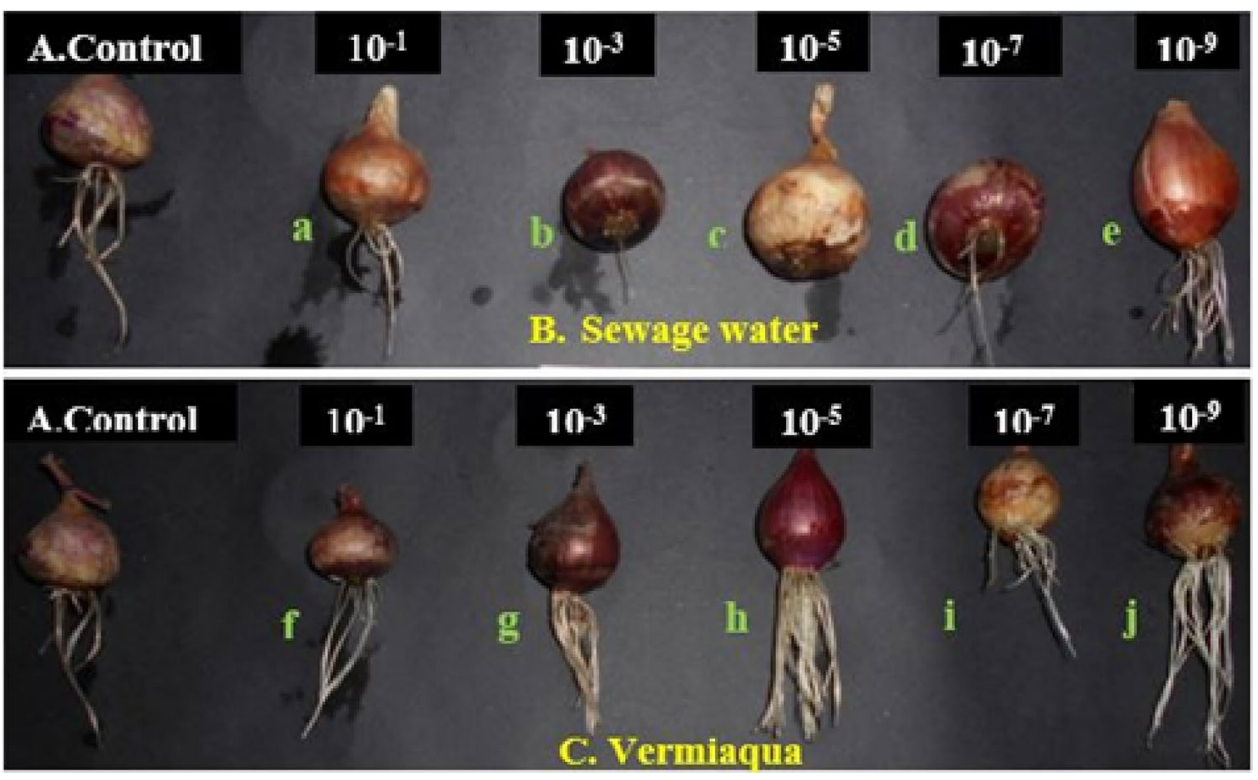

\begin{tabular}{llll}
\hline & Control & Wastewater $\left(10^{-9}\right)$ & Vermiaqua $\left(10^{-5}\right)$ \\
\hline Interphase & No abnormalities & No abnormalities & No abnormalities \\
Prophase & No abnormalities & No abnormalities & No abnormalities \\
Metaphase & Sticky chromosomes & Uneven separation & No abnormalities \\
& Chromosomal deletion & Sticky chromosomes & No abnormalities \\
& & Laggard chromosomes & No abnormalities \\
& & Chromosomal deletion & No abnormalities \\
Anaphase & Sticky chromosomes & Sticky chromosomes & Dibridges \\
Telophase & No abnormalities & No abnormalities & No abnormalities \\
\hline
\end{tabular}

\begin{tabular}{lllll}
\hline Number of roots & $\begin{array}{l}\text { Root length } \\
(\mathrm{cm})\end{array}$ & Root colour & Root forms & \\
\hline $\begin{array}{l}\text { Control } \\
\text { Wastewater }\end{array}$ & 15 & 3.99 & White & Normal and wavy \\
$10^{-1}$ & 11 & 1.78 & White & Retarded and Crochet hook \\
$10^{-3}$ & 03 & 0.8 & White & Inhibited \\
$10^{-5}$ & 00 & 0.0 & White & Zero germination \\
$10^{-7}$ & 04 & 3.6 & White & Inhibited \\
$10^{-9}$ & 16 & 2.2 & White & Stunted, wavy and curly \\
Vermiaqua & & & White & Accelerated and straight \\
$10^{-1}$ & 09 & 3.91 & White & Accelerated and straight \\
$10^{-3}$ & 26 & 2.49 & White & Accelerated and straight \\
$10^{-5}$ & 40 & 3.40 & White & Retarded, wavy and curly \\
$10^{-7}$ & 21 & 2.70 & White & Accelerated and wavy \\
$10^{-9}$ & 24 & 4.68 & &
\end{tabular}

cm centimeter

cmentimeter
Table 4 IMPACTS of

wastewater and vermiaqua on chromosome of germinated roots 


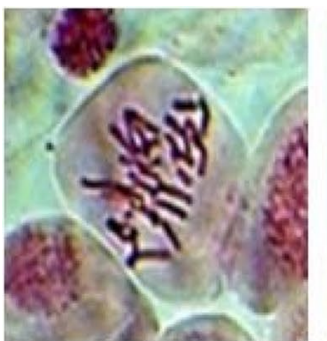

i

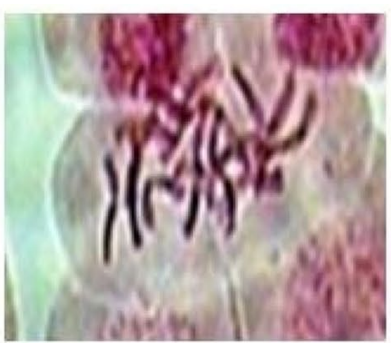

ii

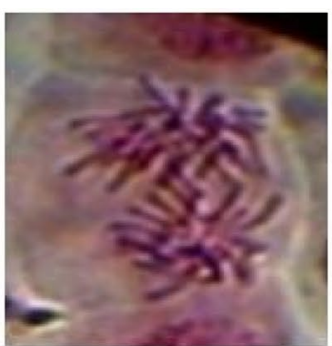

iii

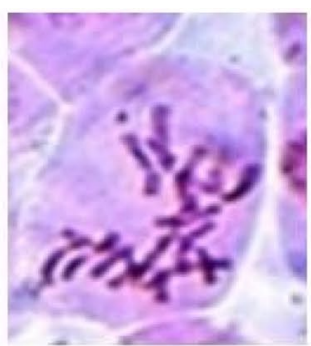

iv

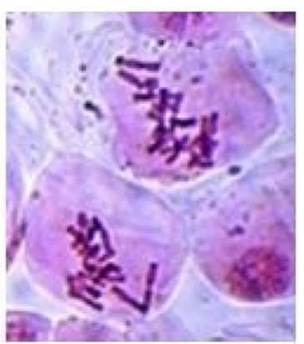

$\mathbf{V}$

Fig. 11 Chromosomal abnormalities observed at $10^{-9}$ wastewater concentration (i uneven metaphase chromosomal separation, ii sticky metaphase chromosome, iii sticky anaphase chromosome, iv laggard metaphase chromosome, v metaphase chromosomal deletion)
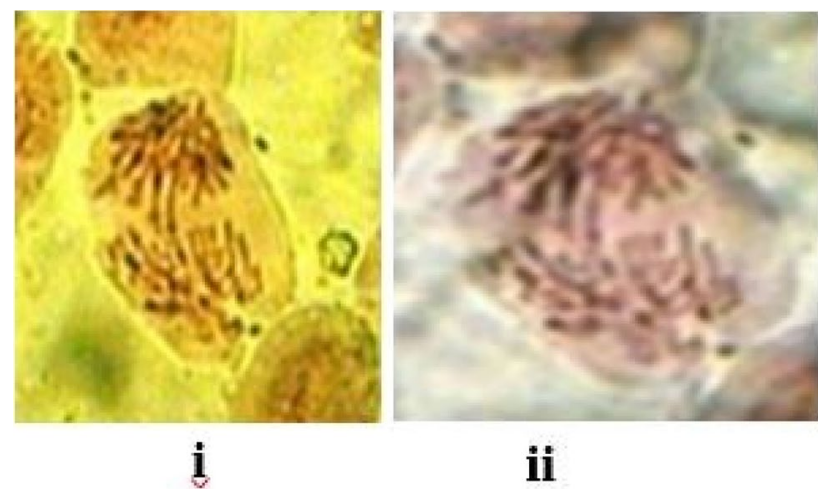

Fig. 12 Chromosomal abnormalities observed at $10^{-5}$ vermiaqua concentration (i, ii anaphase dibridges and chromosomal dibridges)

Acknowledgements We express our deep indebtedness and gratefulness to the Government of India for providing necessary fellowship to complete this research work. We acknowledge Prof. Dr. Rajiv K. Sinha (Former Associate Professor, Griffith University, Australia) for his at present kind help related to research experiments and data. We are also grateful to a Farmer Mr. Arvind Ji (best farmer award winner), Deepak Dairy Farm, Patna, India for his support related to fulfilling the need of Earthworms.

Open Access This article is distributed under the terms of the Creative Commons Attribution 4.0 International License (http://creativeco mmons.org/licenses/by/4.0/), which permits unrestricted use, distribution, and reproduction in any medium, provided you give appropriate credit to the original author(s) and the source, provide a link to the Creative Commons license, and indicate if changes were made.

\section{References}

Amal WA (2002) Cytotoxicity testing of sewage water treatment using Allium cepa chromosome aberrations assay. Pak J Biol Sci 5:184188. https://doi.org/10.3923/pjbs.2002.184.188

Ateeq B, Abul FM, Niamat AM, Ahmad W (2002) Clastogenicity of pentachlorophenol, 2,4-D and butachlor evaluated by Allium root tip test. Mutat Res Genet Toxicol Environ Mutagen 514(1-2):105113. https://doi.org/10.1016/s1383-5718(01)00327-8
Bajsa O, Nair J, Mathew K, Ho GE (2004) Vermiculture as a tool for domestic wastewater management. Water Sci Technol 48(1112):125-132. https://doi.org/10.2166/wst.2004.0821

Bakare AA, Okunola AA, Adetunji OA, Jenmi HB (2009) Genotoxicity assessment of a pharmaceutical effluent using four bioassays. Genet Mol Biol 32(2):373-381. https://doi.org/10.1590/S1415 $-47572009000200026$

Chandra S, Chauhan L, Murthy R, Saxena P, Pande P, Gupta S (2005) Comparative biomonitoring of leachates from hazardous solid waste of two industries using Allium test. Sci Total Environ 347(1-3):46-52. https://doi.org/10.1016/j.scitotenv.2005.01.002

Darwin C (1881) The formation of vegetable mould, through the action of worms: with observations on their habits. https://doi. org/10.5962/bhl.title.107559

Darwin C, Darwin F, Seward AC (1903) More letters of Charles Darwin. A record of his work in a series of hitherto unpublished letters. In: Darwin F, Seward AC. https://doi.org/10.5962/bhl.title .1477

Dash S, Panda KK, Panda BB (1988) Biomonitoring of low levels of mercurial derivatives in water and soil by Allium micronucleus assay. Mutat Res 203(1):11-21. https://doi.org/10.1016/01651161(88)90003-9

Egito LCM, Medeiros MG, Medeiros SRB, Agnez-lima LF (2007) Cytotoxic and genotoxic potential of surface water from the Pitimbu River, North-Eastern Brazil. J Genet Mol Biol 30(2):435441. https://doi.org/10.1590/S1415-47572007000300023

Evseeva TI, Geraskin SA, Shuktomova II (2003) Genotoxicity and toxicity assay of water sampled from a radium production industry storage cell territory by Allium-test. J Environ Radioact 68(3):235-248. https://doi.org/10.1016/S0265-931X(03)00054-7

Firbas P (2013) Allium chromosome aberration test for evaluation effect of cleaning municipal water with constructed wetland $(\mathrm{CW})$ in Sveti Tomaž, Slovenia. J Bioremediat Biodegrad 4:4. https://doi. org/10.4172/2155-6199.1000189

Fiskesjö G (1988) The allium test-an alternative in environmental studies: the relative toxicity of metal ions. Mutat Res 197(2):243260. https://doi.org/10.1016/0027-5107(88)90096-6

Gopalan HN (1999) Ecosystem health and human wellbeing: the mission of the international programme on plant bioassays. Mutat Res 426(2):99-102. https://doi.org/10.1016/S0027-5107(99)00048-2

Grant WF (1999) Higher plant assays for the detection of chromosomal aberrations and gene mutations-a brief historical background on their use for screening and monitoring environmental chemicals. Mutat Res 426(2):107-112. https://doi.org/10.1016/S0027 $-5107(99) 00050-0$

Grover I, Kaur S (1999) Genotoxicity of wastewater samples from sewage and industrial effluent detected by the Allium root anaphase 
aberration and micronucleus assays. Mutat Res 46(2):183-188. https://doi.org/10.1016/S0027-5107(99)00065-2

Hartenstein R, Bisesi MS (1989) Use of earthworm biotechnology for the management of effluents from intensively housed livestock. Outlook Agr 18(2):72-76. https://doi.org/10.1177/0030727089 01800205

Kerr M, Stewart AJ (2003) Tolerance test of eisenia fetida for sodium chloride. Journal of Undergraduate Research 3. DOESC (USDOE Office of Science (SC) the United States) OSTI Identifier:1051306 https://www.osti.gov/biblio/1051306

Komarowski S (2001) Vermiculture for Wastewater and Water Treatment Sludges. Publ Austral Water Wastewater Assoc 28(5):39-43. https://www.researchgate.net/publication/287735439

Markman S, Guschina IA, Barnsley S, Buchanan KL, Pascoe D, Müller CT (2007) Endocrine disrupting chemicals accumulate in earthworms exposed to sewage effluent. Chemosphere 70(1):119-125. https://doi.org/10.1016/j.chemosphere.2007.06.045

OECD (2004) Test No. 222: Earthworm reproduction test (Eisenia fetida/Eisenia andrei). OECD Publishing, Paris. https://doi. org/10.1787/9789264070325-en

Olorunfemi D, Ogieseri U, Akinboro A (2011) Genotoxicity screening of industrial effluents using onion bulbs (Allium cepa $\mathrm{L}$.). J Appl Sci Environ Manage 15(1):211-221. https://doi.org/10.4314/ jasem.v15i1.65700

Rajpal A, Bhargava R, Sasi SK, Chopra A (2011) On-site domestic organic waste treatment through Vermitechnology using indigenous earthworm species. Waste Manag Res 30(3):266-275. https ://doi.org/10.1177/0734242X11403798

Roberts BL, Dorough HW (1985) Hazards of chemicals to earthworms. Environ Toxicol Chem 4(3):307-323. https://doi.org/10.1002/ etc.5620040306

Römbke J, Jänsch S, Didden W (2005) The use of earthworms in ecological soil classification and assessment concepts. Ecotoxicol Environ Saf 62(2):249-265. https://doi.org/10.1016/j.ecoen v.2005.03.027

Sinha RK, Bharambe G, Chaudhari U (2008) Sewage treatment by vermifiltration with synchronous treatment of sludge by earthworms: a low-cost sustainable technology over conventional systems with potential for decentralization. Environmentalist 28(4):409-420. https://doi.org/10.1007/s10669-008-9162-8

Sinha RK, Agarwal S, Chauhan K, Chandran V, Soni BK (2010) Vermiculture technology: reviving the dreams of sir charles darwin for scientific use of earthworms in sustainable development programs. Technol Invest 01(03):155-172. https://doi.org/10.4236/ ti.2010.13019

Sinha RK, Chandran V, Soni BK, Patel U, Ghosh A (2012) Earthworms: nature's chemical managers and detoxifying agents in the environment: an innovative study on treatment of toxic wastewaters from the petroleum industry by vermifiltration technology. Environmentalist 32(4):445-452. https://doi.org/10.1007/s1066 9-012-9409-2

Taylor M, Clarke W, Greenfield P (2003) The treatment of domestic wastewater using small-scale vermicompost filter beds. Ecol Eng 21(2-3):197-203. https://doi.org/10.1016/j.ecoleng.2003.12.003

Ukaegbu MC, Odeigah PGC (2009) The genotoxic effect of sewage effluent on Allium cepa. Rep Opin 6:36-41. http://www.scien cepub.net/report/report0106/06_2042_ukaegbu_report0106.pdf

Valembois P, Roch P, Lassegues M, Cassand P (1982) Antibacterial activity of the hemolytic system from the earthworm Eisenia fetida andrei. J Invertebr Pathol 40(1):21-27. https://doi. org/10.1016/0022-2011(82)90032-5

Viswanathan M, Kim SK, Berdichevsky A, Guarente L (2005) A role for SIR-2.1 regulation of ER Stress response genes in determining C. elegans life span. Dev Cell 9(5):605-615. https://doi. org/10.1016/j.devcel.2005.09.017

Publisher's Note Springer Nature remains neutral with regard to jurisdictional claims in published maps and institutional affiliations. 